\title{
The Reform of the Calendar.
}

SINCE the War a number of ingenious schemes have been put forward for the reform of the calendar. Such an important step should not be taken unadvisedly, lightly, or wantonly, but the advantages claimed should be considered, the extent of the demand for it assessed, and the possibility of finding a scheme which would meet general approval carefully weighed. The League of Nations, being in a position to consult the various bodies which could give authoritative expression to opinion on the subject and the aid of which would be required in carrying out any changes proposed, undertook a full inquiry. It appointed a committee, with Prof. van Eysinga of Leyden as chairman, and with representatives of the Holy See, the Orthodox Church, the Church of England, the International Chamber of Commerce, and the International Astronomical Union upon it. This committee has recently issued a short and valuable report. ${ }^{1}$

The principal defect in the Gregorian Calendar arises from the unequal lengths of months, quarters, and halfyears, which introduce a certain amount of irregularity in statistics, accounts, commercial and transport figures. This is increased somewhat because different days of the week are of unequal value as regards volume of trade, and thus one year or one quarter is not strictly comparable with another.

Minor defects are that special tables are required by banks in their calculations of interest, and that dates of periodical events, for example, the opening of Parliament, cannot be fixed without reference to a calendar. As many as $\mathrm{r} 85$ schemes of reform were received by the committee, including 33 from France, 27 from the United States, 24. from Germany, and 5 from Great Britain. The minimum change proposed was to take a day from August and give it to February. A second suggestion made the months of three of the quarters of the year consist of 30,30 , and $3 \mathrm{I}$ days respectively, and the last quarter of $30,3 \mathrm{r}$, and $3 \mathrm{I}$ days. The question may well be asked whether the advantages are sufficient to justify the change.

A more radical reform is obtained by the use of one day without name in ordinary years and two such days in leap-years. The remaining days of the year may then be divided into 52 weeks, which may be arranged as four quarters of thirteen weeks, the months consisting of 30,30 , and 31 days, or as 13 months of 4 weeks each. The advantages and disadvantages of these two schemes are compared, and preference on the whole given to the former. The committee is satisfied, and

'Publication of the Leaguc of Nations, viii. Transit, 1926, viii. 6 . (London: Constable and Co.) $3 s .6 d$. most people will agree with it, that there is no general demand for these changes, which would be strongly opposed by many religious bodies. Without general assent, confusion would result, and it may be remembered that the Gregorian Calendar was introduced in 1582 , adopted in Scotland in 1600 , but not in England until I75I, and in eastern Europe only six years ago.

The committee next considers the question of fixing or 'stabilising' Easter. At present Easter Sunday varies between March 22 and April 25. This wide range makes difficulties in the arrangement of school and university terms and of public holidays. Many commercial transactions and transport services are prejudiced, in particular, business dealing with textiles, articles of fashion, and the hotel-keeping industry. There appears to be a consensus of opinion in these circles that the second Sunday in April would be the most convenient date. The committee favours a slightly different date, namely, the day following the second Saturday, in order to avoid the contingency of the festival of the Annunciation and Passion Sunday both falling on the same date.

The committee has made general inquiries of the attitude of the heads of different Christian Churches on the stabilisation of Easter. It is agreed that there is no dogmatic reason against a fixed date. It appears that the Church of England and the Greek Church are ready to accept the change if the Church of Rome also accepts it. The Holy See does not consider that there is sufficient reason for changing a date handed down by immemorial tradition and sanctioned by councils from early times, and would not be prepared to consider the question except on the advice of an Ecumenical Council. The Protestant Churches of Europe and America and the Jewish Community raise no objections to the proposal.

The report of the committee of the League of Nations shows that there is a general belief, certainly in England, that the stabilisation of Easter would bring substantial advantages and a wish to see the change made. As there are no difficulties of dogma involved, it may be hoped that ecclesiastical concurrence is not impossible. Incidentally, uniformity in keeping Easter will be secured between the different Churches. At the present time the Greek Church uses the position of the moon to determine Easter, while the tables of Clavius are still retained by the Roman and Anglican Churches. Sometimes the two methods give the same date; frequently they differ a week, and occasionally a month.

F. W $\mathrm{W}^{\top} \mathrm{D}$

\section{Obituary.}

Prof. J. D. F. Gilchrist.

PROF. J. D. F. GILCHRIST, who died recently in Capetown at the age of sixty years, had been in South Africa for thirty-one years. Gilchrist's early university days were spent at -St. Andrews and Edinburgh. At one time he had thought of entering the Presbyterian ministry, but after coming under the influence of inspiring leaders in natural science at St. Ardrews and Edinburgh, he definitely resolved to pursue a biological career. After a period at Münich and Zürich, and at biological stations, more especially that of St. Andrews, he was appointed, on the recommendation of the late Sir John Murray, of the Challenger, and of Prof. M'Intosh, St. Andrews, to the position of Government Marine Biologist at the Cape of Good Hope. Gilchrist was probably the first to hold the title of Government Biologist in any country, and in his later days he was wont to tell his friends about the weary,

$$
\text { NO. } 2978 \text {, VOL. I I } 8]
$$


uphill task he had during his first year, in a government office in Parliament Street, Cape Town, without either laboratory or practical equipment of any kind. $\mathrm{He}$ was, however, able to persuade the Ministry of Agriculture that a vessel for dredging and trawling, a museum for storing the specimens, and a marine laboratory and aquarium were necessary.

Gilchrist was particularly fortunate in securing as the first captain of the government trawler, Alexander Turbyne, a keen fisherman naturalist, who had been trained under the late Sir John Murray. An important practical result of the preliminary surveys of the S.S. Pieter Faure was the discovery in 1898 of a rich fishground on the Agulhas Bank, within easy reach of the markets of Cape Town. This discovery appealed alike to the public and to the Government, and led to greater financial support.

While recognising the necessity of developing the economic aspect of marine biology, Gilchrist always kept the more purely scientific point of view in his mind. The Cape waters had only been explored in a cursory manner by such expeditions as the Challenger and the Gazelle, and thus there was open ground for more thorough investigations. The dredging and trawling expeditions of the Pieter Faure resulted in the capture of more than twenty thousand specimens, the majority of which, with the exception of the fishes, were despatched home to be studied by specialists. From the papers published by these workers, and from his own contributions, Gilchrist edited the volumes "Marine Investigations in South Africa" (r902-I907). In 1907, however, during a period of severe financial depression in the colony, the office of Government Biologist was abolished, but the publications were revived in $19 \mathrm{r} 3$, under a new board, as "Marine Biological Reports of the Cape Province."

From 1905 to I9I7, Gilchrist was professor of zoology in the South African College, and when, in rgr8, the latter developed into the University of Cape Town, he held the chair of zoology until in 1925 ill-health compelled his retirement. After his resignation he still carried on some work at his favourite haunt, the St. James Marine Station, on the shores of Kalk Bay.

Gilchrist was the author of numerous papers, dealing more especially with the description of new or rare species of fish, and of their larval development; but he also contributed publications of more general interest, such as those on the early stages of Cephalodiscus gilchristi, on the enteropneust, Xenopleura vivipara, on the remarkable crawling medusa (Cnidonema capensis, g. et sp. n.), and on the temperature and currents of South African seas.

Sometimes Gilchrist may have conveyed the impression of a man who lived in a little world of his own, wrapped up in thoughts of his fishes and other denizens of the sea, but that he could free himself from these deliberations is proved by his work for science in the colony, as president of the Philosophical and later of the Royal Society of South Africa, and as one of the main organisers of the South African Association for the Advancement of Science.

Gilchrist married Elfreda Ruth, daughter of S. H. Raubenheimer, of George, C.C., and is survived by his widow, a son, and a daughter.

\section{News and Views.}

ONE of the problems to which the Imperial Conference has been devoting attention is the present position of forestry within the British Empire. A sub-committee was set up, which dealt with this matter on broad lines. It is a hopeful augury for the future that the question of a forest policy common to the Empire as a whole, with especial reference to the world's timber supplies, should have been examined in some detail. It is an accepted fact that the avail able virgin supplies of the soft woods (pines and firs) are giving out, Canada and north Russia and Siberia containing the chief remaining stocks. About eighty per cent. of the wood used for industrial purposes consists of the soft woods. As regards the hard woods, the available supplies of these from temperate climates are not regarded as satisfactory, and their replacement by tropical hard woods offers difficulties which are very far from solution. Apart from the question of the availability of the existing supplies to meet demands, there exist social and economic problems which make it necessary that each country, and perhaps more especially the British Empire, should formulate a policy which shall maintain a sufficient forest area under a conservative forest management. At the present day a large proportion of the Empire forests have little that can be termed a scientific conservative management in being; the Imperial Conference will have made a long step forward if, as a result of the deliberations and recommendations of the sub-committee, a consistent forest policy is formulated and adhered to. Other matters given consideration were Empire settlement and its connexion with forestry, the meeting of the Empire Forestry Conference in Australia and New Zealand in 1928 , forest products research work, and the proposed inauguration of an Imperial Forestry Bureau.

THE silver medal of the Zoological Society of London has been awarded to Capt. H. C. Brocklehurst, the Game Warden of the Sudan, in recognition of his services to the Society, and for the active part which he has taken in the preservation of the wild fauna of that part of Africa. The medal, which was designed by Landseer, has been awarded on forty-eight previous occasions, the first recipient being Sir Roderick Murchison, in 1847 , "for assisting in the introduction of the Aurochs." Capt. Brocklehurst has been instrumental in obtaining several valuable collections of animals for the London Zoo. The last of these included two giraffes, two Sudanese oryx, and three shoebills, or whaleheaded storks; now one of the rarest birds in the world. The white rhinoceros, which a little time ago was threatened with extinction, comes directly under Capt. Brocklehurst's care, and it is reassuring to hear from him that, owing to the proper administration of suitable game laws, this wonderful

$$
\text { NO. } 2978 \text {, VOL. I I } 8 \text { ] }
$$

